\title{
Dairy goat health management and milk production on organic and conventional system in Brazil
}

\section{Estudo comparativo da produção e manejo sanitário entre cabras leiteiras orgânica e convencional no Brasil}

\author{
Jenevaldo Barbosa da Silva ${ }^{1 *}$; Gisele Maria Fagundes ${ }^{2}$; \\ João Paulo Guimarães Soares ${ }^{3}$; Adivaldo Henrique Fonseca ${ }^{4}$
}

\begin{abstract}
The aimed of this article is to measure risk factors on health and milk production on organic and conventional dairy goats in Brazil. Two experimental groups (organic and conventional) were evaluated simultaneously. The study design was completely randomized. The organic herd consisted of 25 goats and 15 kids. In the conventional production system, a dairy herd comprising 40 goats and 20 kids participated in the study. Data on milk production and health management were available from January 2007 to December 2009. The abortion rate in the conventional system was 5\% (2/40) whereas in organic system no abortion was diagnosed $(0 / 25)$. The mortality rate at weaning in the conventional system was $5 \%(2 / 40)$ and in the organic system was $8 \%(2 / 25)$. Milk production was lower $(2.20 \mathrm{~kg} /$ day $)$ in organic than conventional system $(2.66 \mathrm{~kg} /$ day). Goats and kids in organic farm had a higher FEC (386 \pm 104 and $900 \pm 204$, respectively) $(p<0.05)$ than those in conventional farm $(245 \pm 132$ and $634 \pm 212$, respectively). In addition, Saanen kids had higher FEC $(\mathrm{p}<0.001)$ than goats. Treatment with antiparasitic drugs was higher in conventional system $(50 \%)$ than organic system (1.3\%).
\end{abstract}

Key words: Conventional system, goat, milk production, organic system, parasites

\section{Resumo}

O objetivo do artigo foi mensurar os fatores de risco referentes ao manejo sanitário e a produção entre cabras leiteiras sob sistema orgânico e convencional. Dois grupos experimentais (orgânico e convencional) foram conduzidos simultaneamente. $\mathrm{O}$ desenho do estudo foi o inteiramente casualizado. $\mathrm{O}$ rebanho orgânico consistiu de 25 cabras e 15 cabritos e o sistema convencional por 40 cabras e 20 cabritos. Os parâmetros produtivos e sanitários foram monitorados entre janeiro de 2007 a dezembro de 2009. No sistema convencional, houve uma taxa de aborto de 5\% (2/40), enquanto que no sistema orgânico nenhum aborto foi diagnosticado (0/25). A taxa de mortalidade ao desmame no sistema convencional foi de 5\% (2/40) e no sistema orgânico foi de $8 \%(2 / 25)$. A produção de leite média diária por cabra no rebanho leiteiro orgânico $(2,20 \mathrm{~kg} / \mathrm{dia})$ foi mais baixa do que a do rebanho convencional $(2,66 \mathrm{~kg} / \mathrm{dia})$. Os resultados indicaram que as cabras e cabritos mantidos em fazenda orgânica (386 \pm 104 e $900 \pm 204$, respectivamente) apresentaram maiores valores de OPG $(\mathrm{p}<0,05)$ do que aqueles mantidos em fazenda convencional ( $245 \pm 132$ e $634 \pm 212$, respectivamente). O valor médio de OPG nos animais jovens foi superior $(\mathrm{P}<0,001)$ ao dos animais adultos. A utilização de antiparasitário foi significativamente maior no sistema convencional (50\%) quando comparado ao sistema orgânico (1.3\%).

Palavras-chave: Cabra, produção de leite, sistema convencional, sistema orgânico, helmintos

\footnotetext{
${ }^{1}$ Discente da Faculdade de Ciências Agrárias e Veterinária, Universidade Estadual Paulista, FCAV/UNESP, Jaboticabal SP. E-mail: jenevaldo@hotmail.com

${ }^{2}$ Discente do Centro de Energia Nuclear na Agricultura, Universidade de São Paulo, CENA/USP, Piracicaba SP. E-mail: giselefagundes22@hotmail.com

${ }_{3}^{3}$ Pesquisador da Empresa Brasileira de Pesquisa Agropecuária, EMBRAPA, Brasília, DF. E-mail: jp.soares@cpac.embrapa.br

${ }^{4}$ Prof. da Universidade Federal Rural do Rio de Janeiro, UFRRJ, Seropédica, RJ. E-mail: adivaldo@ufrrj.br

* Author for correspondence
} 


\section{Introduction}

Disease caused by internal and external parasites is, arguably, one of the most important health constraints affecting productivity in small ruminants kept in organic system. This is of particular importance for many tropical and subtropical countries where goats play a vital role in the agricultural economies (JACKSON; VARADY; BARTLEY, 2012). In goats at pasture, parasitized animals have reduced the efficiency of production by decreasing voluntary feed intake, live weight gain, milk yield, and carcass quality (MORENOGONZALO et al., 2012).

Organic agriculture has expanded in Brazil over the last five years (SOARES et al., 2012). In 2005, the organic milk production in Brazil was estimated to $0.01 \%$ (2.4 million liters) of the total milk production. However, in 2010, this production had increased to $0.02 \%$ (6.8 million liters) of the national milk production (SOARES et al., 2012).

There is not only a consumer interest for these products but also a political (CEDEBERG AND MATTSSON, 2000) and environmental one. The growth of markets increasingly interested in products with no chemicals has encouraged producers in agroexporting countries to adopt organic production systems (SILVA; FAGUNDES; FONSECA, 2011). Despite anthelmintics are not always used in conventional farms (HÖGLUND et al., 2010), the growing consumer concern and increasing awareness among veterinarians of chemotherapeutic resistance have resulted in stricter control of use of veterinary medicines (THAMSBORG; ROEPSTORFF; LARSEN, 1999). Indeed, the prohibition of prophylactic anthelmintics, is a crucial aspect should be taken into account in organic livestock production.

Furthermore, the extensive use of these chemicals seems to be the origin of the possible development parasite resistance. Goats have had a long established link with anthelmintic resistance and many of the earliest cases of multiple resistances were reported (PARAUD et al., 2009). In addition, common external parasites and bacterial diseases may cause several problems to animal health. Thus, this article aimed to measure risk factors on health management and milk production on organic and conventional dairy goats in Brazil.

\section{Materials and Methods}

\section{Experimental area}

This study was conducted from January 2007 to December 2009 as collaboration between Embrapa Agrobiologia and Universidade Federal Rural of Rio de Janeiro (UFRRJ). Data were collected from 2 dairy herds in southeast of Brazil, in the municipality of Seropédica, Rio de Janeiro, located at latitude $45^{\prime} \mathrm{S} 22^{\text {nd }}, 43^{\text {rd }} 41^{\prime} \mathrm{W}$ longitude GRW and altitude of $33 \mathrm{~m}$.

\section{Experimental design}

The study was conducted in two dairy goat herds for 3 consecutive years (2007-2009). Two experimental groups (organic and conventional) were evaluated simultaneously. The study design was completely randomized. The experimental group consisted of 40 goats ( 25 goats and 15 kids) kept in an organic production system and 60 goats (40 goat and 20 kids) under conventional production system. Data from conventional and organic herds was obtained at the Universidade Federal Rural of Rio de Janeiro (UFRRJ). A total of 100 dairy Saanen goats suffering from natural infection were evaluated. All goats were milked twice a day during lactation period. Two herds were visited monthly; totaling 36 visits during the three years of study.

The following health and production variables were investigated: numbers of gastrointestinal nematode eggs per gram of feces, numbers of oocysts per gram of feces, abortions, clinical mastitis, tick counts, louse counts, lameness, antiparasitic use, parasitic resistance, milk yield, labor interval, live- 
weight gain in young, young mortality, lactation period, lactating animals, stocking area. The tick counts, louse counts and lameness variables were categorized: absence, low, medium and high. The antiparasitic use variable was categorized: casual, low, medium and high.

\section{Organic system}

In the organic farm the goats were kept in 6 pasture (Brachiaria humidicola) paddocks at rotational system (5 days), each measuring about $1.5 \mathrm{ha}$, stocked at 2.2 ha/AU. During the dry season (April-September), the goats received Tifton 85 hay (Cynodon spp. hybrid) as roughage supplement and maize silage (Zea mays) ad libitum. The parasite control performed on the organic farming was based on rotational grazing, separation of animals by class and according to age, adequate nutrition and roughage supplement (hay and silage). The animals were divided into three groups according to age. The first group consisted for animals of $0-6$ months, the second for animals of 7-12 months and the third for animals older than one year.

\section{Conventional system}

In the conventional system the goats and kids were kept in Brachiaria decumbens stocked at 4.4 ha/AU. The goats fed $1 \mathrm{~kg}$ day of concentrate with $22 \%$ crude protein. During the dry season, the goats received elephant grass (Pennisetum purpureum Schum cv. cameroon) and sugarcane (Saccharum spp.) as roughage supplement. The animals under conventional system were dewormed at monthly using levamisole phosphate $\left(10 \mathrm{mg} / \mathrm{kg}\right.$, Ripercol ${ }^{\circledR}$ L 150 F, Fort Dodge, Brazil) and Albendazole (10 $\mathrm{mg} / \mathrm{kg}$, Valbazen ${ }^{\circledR} 10$ Cobalto, Pfizer, Brazil). Anthelmintic rotation was used, with a different active principle employed in each month.

\section{Clinical mastitis}

Clinical mastitis (CM) was defined as a goat having a swollen or hard udder or noticeable clots or strings in its milk. Recurrent episodes of disease were counted as the same case if the recurrence occurred within 2 weeks of initial onset. Animals with multiple quarters affected with $\mathrm{CM}$ were counted as the same case. The CM rate for each herd was calculated as the number of CM cases per 100 goat-years at risk.

\section{Fecal egg count}

Fecal samples were collected fortnightly from all goats during the study. The numbers of gastrointestinal nematode eggs per gram of feces (EPG), from nematodes gastrointestinal and oocyst of protozoa were counted using the McMaster technique, as described by Gordon and Whitlock (1939).

\section{Tick counts}

To ticks counts, the animals were restrained individually, and all the fully or partially engorged females of Rhipicephalus microplus or Amblyomma cajennese measuring between 4.5 and $8.0 \mathrm{~mm}$ that were found on the right side of each animal were counted as described by Wharton et al. (1970). The result from each count was multiplied by 2 to obtain the monthly average for each animal.

\section{Tick Susceptibility}

Test Immersion Adults (Ivermectin 1\%) was employed to evaluate the in vitro tick susceptibility (DRUMMOND et al., 1973). The World Association for the Advancement of Veterinary Parasitology (WAAVP) by Coles et al. (1992) methods for the detection of anthelmintic resistance in nematodes were performed. 


\section{Statistical analysis}

For statistical analysis, the EPG data were initially transformed into $\log _{10}(x+1)$ in order to normalize them. For quantitative assessment of different parameters, analysis of variance was used, along with the Tukey test at 5\% significance. The operating procedures were performed using the statistical software R Foundation for Statistical Computing, version 2.12.2 (2011).

\section{Results}

The health and productive parameters in dairy goats are shown in Table 1 and 2. The abortion rate in the conventional system was $5 \%(2 / 40)$ whereas in organic system no abortion was diagnosed (0/25). The mortality rate at weaning in the conventional system was $5 \%(2 / 40)$ and in the organic system was $8 \%(2 / 25)$. The number of twin pregnancies, birth weight and weaning did not differ $(p>0.05)$ among the two systems.

Milk production $(2.6 \mathrm{~kg} /$ day $)$ in conventional system was higher than in the organic system $(2.2 \mathrm{~kg} /$ day $)$. As can be noted in Table 1, milk yield per goat was $21 \%$ lower on the organic farm compared with the conventional farm $(\mathrm{p}=0.021)$. As expected, treatment with antiparasitic was higher in conventional system (50\%) than organic system $(1.3 \%)$.

Table 1. Management and production variables on organic and conventional dairy goat.

\begin{tabular}{|c|c|c|c|c|c|c|}
\hline \multirow{2}{*}{ Productive parameters } & \multicolumn{2}{|c|}{ Goat (2007) } & \multicolumn{2}{|r|}{ Goat (2008) } & \multicolumn{2}{|c|}{ Goat (2009) } \\
\hline & Organic & Conventional & Organic & Conventional & Organic & Conventional \\
\hline Number of lactating goats & 25 & 40 & 25 & 40 & 25 & 40 \\
\hline Milk yield (kg/day) & $2.0 \pm 0.422$ & $2.4 \pm 0.234$ & $2.0 \pm 0.978$ & $3.0 \pm 0.472$ & $1.4 \pm 0.812$ & $2.6 \pm 0.338$ \\
\hline Kiding interval (months) & $12 \pm 1.2$ & $10 \pm 1.0$ & $11.5 \pm 1.4$ & $12 \pm 1.1$ & $12 \pm 1.5$ & $11 \pm 1.1$ \\
\hline Live-weight gain in kid (g/day) & $90 \pm 17.2$ & $180 \pm 12.3$ & $108 \pm 18.2$ & $118 \pm 10.3$ & $95 \pm 15.3$ & $112 \pm 14.2$ \\
\hline Lactation period (days) & $270 \pm 10$ & $240 \pm 8$ & $265 \pm 30$ & $240 \pm 10$ & $270 \pm 15$ & $240 \pm 12$ \\
\hline Kid mortality & $8.0 \%$ & $5.0 \%$ & $4.0 \%$ & $2.5 \%$ & $0.0 \%$ & $5.0 \%$ \\
\hline Lactating goat $(\%)$ & $68 \%$ & $70 \%$ & $80 \%$ & $87.5 \%$ & $92 \%$ & $90.0 \%$ \\
\hline Stocking area (animals/ha) & 10 & 20 & 10 & 20 & 10 & 20 \\
\hline
\end{tabular}

Source: Elaboration of the authors.

Table 2. Sanitary parameters on organic ( $\mathrm{n}=25$ goats and $15 \mathrm{kids})$ and conventional system ( $\mathrm{n}=40$ goats and 20 kids).

\begin{tabular}{lcccccc}
\hline \multirow{2}{*}{ Health parameters } & \multicolumn{3}{c}{ Goat (2007) } & \multicolumn{2}{c}{ Goat (2008) } & \multicolumn{2}{c}{ Goat (2009) } \\
\cline { 2 - 6 } & Organic & Conventional & Organic & Conventional & Organic & Conventional \\
\hline FEC*adult animals & $470 \pm 56$ & $250 \pm 108$ & $370 \pm 186$ & $300 \pm 121$ & $200 \pm 145$ & $290 \pm 112$ \\
FEC*/ young animals & $1000 \pm 345$ & $600 \pm 210$ & $950 \pm 400$ & $710 \pm 320$ & $750 \pm 210$ & $670 \pm 150$ \\
Tick count & $0 \pm 0$ & $10 \pm 8$ & $0 \pm 0$ & $5 \pm 5$ & $0 \pm 0$ & $10 \pm 5$ \\
Louse count & $0 \pm 0$ & $5 \pm 3$ & $2 \pm 2$ & $0 \pm 0$ & $0 \pm 0$ & $0 \pm 0$ \\
Number of cases of lameness & 0 & 2 & 0 & 0 & 2 & 0 \\
Abortions (\%) & $0.0 \%$ & $5.0 \%$ & $4.0 \%$ & $2.5 \%$ & $0.0 \%$ & $5.0 \%$ \\
Clinical mastitis (\%) & $4.0 \%$ & $5.0 \%$ & $8.0 \%$ & $7.5 \%$ & $4.0 \%$ & $5.0 \%$ \\
Antiparasitic use (\%) & $0.0 \%$ & $25.0 \%$ & $4.0 \%$ & $50.0 \%$ & $0.0 \%$ & $75.0 \%$ \\
\hline
\end{tabular}

$* \mathrm{FEC}=$ Fecal Egg Count

Source: Elaboration of the authors. 
There were no differences $(p>0.05)$ in fecal egg count between herds in all years of the study. Despite no access to anthelmintic treatment on organic farm, egg counts remained moderate and did not exceed $1000 \mathrm{EPG} /$ animal. However, in the conventional herd, it was $710 \mathrm{EPG} / \mathrm{animal}$, even under anthelmintic conditions (Table 2).

The mean fecal egg count in goats under organic and conventional systems is shown in Table 3. In this study, Trichostrongyloidea, Trichuris spp., Strongyloides papillosus, Toxocara vitulorum, Moniezia expansa and Eimeria spp. was found. No treated goats under organic conditions had higher FEC $(p<0.05)$ than animals throughout conventional system. In addition, Saanen kids had higher FEC $(\mathrm{p}<0.001)$ than goats.

\section{Discussion}

The high coefficients of variation for most variables observed on the study confirms the results reported by Toro-Mujica et al. (2011), indicating the diversity of productive-factor handling techniques in both systems.

The decrease milk production, low reproductive efficiency and an increase in cost of land and hand labor in the organic system, provide high costs per liter of milk produced. According to Soares et al. (2012), organic milk production in Brazil is economically viable, since a capital return of $5 \%$ per year higher than $2 \%$ per year obtained by the conventional system is possible. Thus, the reduction in milk yield is compensated by the higher added value of milk.
Treatment with antiparasitic drugs was higher in conventional system $(50 \%)$ than organic system (1.3\%). This finding corroborates two recent reports (SVENSSON; HESSLE; HOGLUND, 2000; SILVA; FAGUNDES; FONSECA, 2011) whose observed a high incidence in antiparasitic drugs in conventional system.

Although in the present study, organic herd showed higher FEC values than conventional herd during three years study period, the results were satisfactory. Since the organic system is selfsustaining, environmentally correct and animal welfare-promoting, the parasite load is considered tolerable and compatible with the production model (SILVA; FAGUNDES; FONSECA, 2011).

Since degree of gastrointestinal parasitism is very high in tropical and subtropical areas, especially in genetically improved animals, like Saanen (AMARANTE et al., 2004), a greater fecal egg counts were expected. Nevertheless, a nutritional manipulation can be considered as a tool that can help to control infections with gastrointestinal parasitism in goats reducing their dependence on conventional anthelmintic treatments (TORRESACOSTA et al., 2012).

Internal parasites are one of the main causes for lower heifer growth and reduced milk production in older animals (SATO et al., 2005). Anthelmintic treatment is prohibited on organic dairy farms, so the prevalence of gastrointestinal nematodes in organic goats could expectedly be higher than what is commonly found in conventional dairy herds. Therefore, our results may indicate that the organic farms may have a greater worm burden because of the increased use of grazing. 
Table 3. Fecal egg count (FEC) values (average and standard deviation) among goats and kids maintained in the organic and conventional production systems.

\begin{tabular}{lccccc}
\hline Animals & Trichostrongyloidea & Trichuris spp. & S. papilosus & Moniezia benedeni & Eimeria spp. \\
\hline Goat of organic & $386.00 \pm 104^{\mathrm{Ca}}$ & $160.00 \pm 20^{\mathrm{Ac}}$ & $00.00 \pm 75^{\mathrm{Bd}}$ & $120.20 \pm 60^{\mathrm{Ac}}$ & $290.00 \pm 90^{\mathrm{Cb}}$ \\
Goat of conventional & $245.00 \pm 132^{\mathrm{Ca}}$ & $100.00 \pm 18^{\mathrm{Bb}}$ & $00.00 \pm 90^{\mathrm{Bd}}$ & $50.00 \pm 22^{\mathrm{Bc}}$ & $180.45 \pm 76^{\mathrm{Ba}}$ \\
Kid of organic & $900.50 \pm 204^{\mathrm{Aa}}$ & $12.00 \pm 32^{\mathrm{Cd}}$ & $190.50 \pm 121^{\mathrm{Ab}}$ & $100.00 \pm 31^{\mathrm{Ac}}$ & $1200.00 \pm 245^{\mathrm{Aa}}$ \\
Kid of conventional $^{\mathrm{Aa}}$ & $634.112 \pm 212^{\mathrm{Ba}}$ & $10.00 \pm 43^{\mathrm{CD}}$ & $160.00 \pm 50^{\mathrm{Ab}}$ & $45.00 \pm 89^{\mathrm{Bc}}$ & $626.34 \pm 260^{\mathrm{Ba}}$ \\
\hline
\end{tabular}

Average and standard deviation followed by capital letters in the same column and lower case differ among themselves by parametric Tukey test at $5 \%$ of probability respectively.

Source: Elaboration of the authors.

\section{Conclusion}

The low levels of parasitism observed in goats raised under organic system were considered satisfactory, since the control strategy aim was to maintain low levels infection and not achieve a complete eradication of the parasites.

The distribution of gastrointestinal helminthes of Saanen goats in organic production system did not constitute a health risk for the animals. However, the results suggest that even among wellmanaged adult, kids are an important risk factor in the epidemiology of gastrointestinal nematode infections.

Conversely, certain managements, like rotational grazing, pasture rest periods, nutritional supplementation and stocking rate play an important role in the gastrointestinal nematodes control on organic dairy farms.

\section{References}

AMARANTE, A. F. T.; BRICARELLO, P. A.; ROCHA, R. A.; GENNARI, S. M. Resistance of Santa Ines Suffolk and Ile de France lambs to naturally acquired gastrointestinal nematode infections. Veterinary Parasitology, Amsterdam, v. 120, n. 1-2, p. 91-106, 2004.

CEDERBERG, C.; MATTSSON, B. Life cycle assessment of milk production - a comparison of conventional and organic farming. Journal of Cleaner Production, Knoxville, v. 8, n. 1, p. 49-60, 2000.

COLES, G. C.; BAUER, C.; BORGSTEEDE, F. H. M.; GEERTS, S.; KLEI, T. R.; TAYLOR, M. A.; WALLER, P. J. World Association for the Advancement of Veterinary
(W.A.A.V.P.) methods for the detection of anthelintic resistence in nematodes of veterinary importance. Veterinary Parasitology, Amsterdam, v. 44, n. 1, p. 3544, 1992.

DRUMMOND, R. O.; ERNST, S. E.; TREVINO, J. L.; GLADNEY, W. J.; GRAHAM, O. H. Boophilus annulatus and B. microplus: laboratory tests of insecticides. Journal of Economic Entomology, Lanham, v. 66, n. 1, p. 130133, 1973.

GORDON, H.; WHITLOCK, H. V. A new technique for counting nematode eggs in sheep faeces. Journal of the Council for Scientific and Industrial Research, New Delhi, v. 12, n. 1, p. 50-52, 1939.

HÖGLUND, J.; DAHLSTRÖMB, F.; ENGSTRÖMB, A.; HESSLEB, A.; JAKUBEKA, E.; SCHNIEDERC, T.; STRUBEC, C.; SOLLENBERGA, S. Antibodies to major pasture borne helminth infections in bulk-tank milk samples from organic and nearby conventional dairy herds in south-central Sweden. Veterinary Parasitology, Amsterdam, v. 171, n. 3-4, p. 293-299, 2010.

JACKSON, F.; VARADY, M.; BARTLEY, D. J. Managing anthelmintic resistance in goats - can we learn lessons from sheep? Small Ruminant Research, Thessaloniki, v. 103, n. 1, p. 3-9, 2012.

MORENO-GONZALO, J.; FERRE, I.; CELAYA, R.; FRUTOS, P.; FERREIRA, L. M. M.; HERVÁS, G.; GARCÍA，U.; ORTEGA-MORA，L. M.; OSORO, K. Potential use of heather to control gastrointestinal nematodes in goats. Small Ruminant Research, Thessaloniki, v. 103, n. 1, p. 60-68, 2012.

PARAUD, C.: KULO, A.; PORS, I.; CHARTIER, C. Resistance of goat nematodes to multiple anthelmintics on a farm in France. Veterinary Record, Birmingham, v. 164, n. 3, p. 563-564, 2009.

$\mathrm{R}$ DEVELOPMENT CORE TEAM. R: a language and environment for statistical computing. Vienna: $\mathrm{R}$ Foundation for Statistical Computing, 2011. Disponível 
em: <http://www.R-project.org>. Acesso em: 20 fev. 2011.

SATO, K.; BARTLETT, P. C.; ERSKINE, R. J.; KANEENE, J. B. A comparison of production and management between Wisconsin organic and conventional dairy herds. Livestock Production Science, Foulum, v. 93, n. 2, p. 105-115, 2005.

SILVA, J. B.; FAGUNDES, G. M.; FONSECA, A. H. Dynamics of gastrointestinal parasitoses in goats kept in organic and conventional production systems in Brazil. Small Ruminant Research, Thessaloniki, v. 98, n. 1-3, p. 35-38, 2011.

SOARES, J. P. G.; SALMAN, A. K. D.; AROEIRA, L. M. J.; FONSECA, A. H.; SANAVRIA, A.; SILVA, J. B.; FAGUNDES, G. M. Organic milk production in Brazil: technologies for sustainable production. ICROFS News, Dinamarca, v. 1, n. 1, p. 6-9, 2012.

SVENSSON, C.; HESSLE, C.; HOGLUND, J. Parasite control methods in organic and conventional dairy herds in Sweden. Livestock. Production Science, Maryland, v. 66, n. 1, p. 57-69, 2000.
THAMSBORG, S. M.; ROEPSTORFF, A.; LARSEN, M. Integrated and biological control of parasites in organic and conventional production systems. Veterinary Parasitology, Amsterdam, v. 84, p. 169-186, 1999.

TORRES-ACOSTA, J. F. J.; SANDOVAL-CASTRO, C. A.; HOSTE, H.; AGUILAR-CABALLERO, A. J.; CÁMARA-SARMIENTO, R.; ALONSO-DÍAZ, M. A. Nutritional manipulation of sheep and goats for the control of gastrointestinal nematodes under hot humid and subhumid tropical conditions. Small Ruminant Research, Thessaloniki, v. 103, n. 1, p. 3-9, 2012.

TORO-MUJICA, P.; GARCÍA, A.; GÓMEZ-CASTRO, A. G.; ACERO, R.; PEREA, J.; RODRÍGUEZESTÉVEZ, V.; AQUILAR, C.; VERA, R. Technical efficiency and viability of organic dairy sheep farming systems in a traditional area for sheep production in Spain. Small Ruminant Research, Thessaloniki, v. 100, n. 2, p. 89-95, 2011.

WHARTON, R. H.; UTECH, K. B. W.; TURNER, H. G. Resistance to cattle tick, Boophilus microplus in a herd of Australian Illawarra Shorthorn Cattle - its assessment and heritability. Australian Journal of Agricultural Economics, Canberra, v. 21, n. 1, p. 163-181, 1970. 
